\title{
UTILITY OF PRECISION AGRICULTURE PRACTICES FOR SUSTAINABLE BIO- DIVERSITY MANAGEMENT IN INDIA
}

\author{
Rameshwar Soni \\ School of Studies in Commerce,Vikram University,Ujjain,MP,India \\ Corresponding author Email : mittalshraddha@gmail.com
}

\begin{abstract}
:
The agricultural sector has the unique ability to provide society with a positive contribution to biodiversity whilst producing food. Agriculture is at the origin of many ecosystems with high biodiversity and contributes to the maintenance of a diversity of species and a large gene pool. Even if agricultural land serves first and foremost towards the production of healthy and high quality food and renewable raw materials, the preservation of biodiversity and sustainable agricultural activity are inextricably linked. In such scenario precision agriculture has become a cornerstone of sustainable agriculture, since it respects crops, soils and farmers. Sustainable agriculture seeks to assure a continued supply of food within the ecological, economic and social limits required to sustain production in the long term. Precision agriculture therefore seeks to use high-tech systems in pursuit of this goal. The present paper tried to show the utility for adoption of precision agriculture for farmers in developing country like India to achieve efficient crop production with sustainable bio diversity conservation. Precision agriculture collects and interprets huge amount of data from the field so as to understand the causes of variability and propose strategies for field management, biological species geographic distribution models, based on ecological niche concepts, combine species presence and absence points with environmental biotic and abiotic data, in order to generate models that describe probabilistic distributions of that species - represented as geographical distribution maps for biodiversity management.
\end{abstract}

\section{Keywords:}

Crop production management, Environmental protection, Bio Diversity, economies of return

\section{Introduction:}

The Indian green revolution is also associated with negative ecological /environmental consequences. The status of Indian environment shows that, in India, about 182 million ha of the country‘s total geographical area of 328.7 million ha is affected by land degradation of this 141.33 million ha are due to water erosion, 11.50 million ha due to wind erosion and 12.63 and 13.24 
million ha due to water logging and chemical deterioration (salinization and loss of nutrients) respectively. On the other end, India shares 17 per cent of world's population with 2.5 per cent of geographical area, 1 per cent of gross world product, 4 per cent of world carbon emission and hardly 2 per cent of world forest area. The Indian status on environment is though not alarming when compared to developed countries, it gives an early warning to take appropriate precautionary measures. The Indian green revolution is also associated with negative ecological / environmental consequences. The status of Indian environment shows that, in India, about 182 million ha of the country's total geographical area of 328.7 million ha is affected by land degradation of this 141.33 million ha are due to water erosion, 11.50 million ha due to wind erosion and 12.63 and 13.24 million ha due to water logging and chemical deterioration (Stalinization and loss of nutrients) respectively.The agronomic feasibility of precision agriculture has been intuitive, depending largely on the application of traditional arrangement recommendations at finer scales.The agronomic success of precision agriculture has been quite convincing in crops like sugar beet, sugarcane, tea and coffee. The potential for economic, environmental and social benefits of precision agriculture is largely unrealized because the space-time continuum of crop production has not been adequately addressed. Successful implementation of precision agriculture depends on numerous factors, including the extent to which conditions within a field are known and manage, the adequacy of input recommendation and the degree of application control.The enabling technologies of precision agriculture can be grouped in to fine major categories: Computers,Global Positioning System (GPS), Geographic Information System (GIS), Remote Sensing (RS) and Application control. The various aspects of precision agriculture encompass a broad array of topics including variability of the soil resource base, weather, plant genetics, crop diversity, machinery performance and most physical, chemical and biological inputs used in crop production. 
Material and Method:

Basic Steps in Adoption of Precision Farming

\section{Result and Discussion:}

The basic steps in precision farming are,

\section{Conclusion:}

Precision agriculture is based on a set of resources that allow field variability management. The main idea is to identify areas which present different levels of productivity, and offer an individual treatment for each of them, managing these differences. This concept dates from the 80 s and started a revolution in the resources management (Robert, 2002). Since site-specific management, site-specific farming, or precision farming, alternative names for precision agriculture, has been directed to intensive data and technology usage, resulting in relevant researches, such as those presented in Plant (2001), Zhangh et al.

(2002) and Korduan et. al (2004), and a large amount of products, systems and devices for rising production profitability, improving production quality and helping environment protection. Some examples of precision agriculture purposes include soil properties study for the application of fertilizers in variable rate, and the main aims and other potential benefits of its adoption are to increase productivity,

\section{Reference:}

Iida, M., Umeda, M., Kaho, T., Lee, C.K. and Suguri, M., 1998, Measurement of Annual 